\title{
COMPOSIÇÃO FOTOJORNALÍSTICA E HISTÓRIA: função testemunhal como ato performativo e interação de linguagens
}

\section{PHOTOJOURNALISTIC COMPOSITION AND HISTORY: testimonial function as performative act and languages interactions}

Eliza Bachega CASADEI ${ }^{1}$

Resumo: A partir do pressuposto de que o caráter de testemunho no fotojornalismo deve ser entendido como uma articulação histórica e como um ato performativo, o objetivo do presente artigo é discutir o modo como a função testemunhal da fotografia jornalística foi constantemente ressignificada nas revistas brasileiras de informação ao longo do século XX. Tal ressignificação tem relação com os diferentes modos em que a própria função testemunhal esteve articulada à reportagem (em seus elementos mais amplos) e a forma como esse imperativo aparecia em sua forma discursiva na narrativa escrita. Como fiduciário de uma narrativa que se pretende realista, o fotojornalismo articula, a partir de técnicas e códigos de narração diversos, uma série de estratégias referenciais e informativas que, contudo, mudaram com o passar do tempo, articulando diferentes modos de narração pela imagem e de credenciamento perante o real.

Palavras-Chave: Fotojornalismo. Função Testemunhal. História.

\footnotetext{
Abstract: Assuming that testimony in photojournalism must be understood as a historical and performative act, the aim of this article is to discuss how the testimonial function of

${ }^{1}$ Doutora em Ciências da Comunicação pela Escola de Comunicações e Artes da Universidade de São Paulo (ECA-USP) e professora da Faculdade de Arquitetura, Artes e Comunicação da Universidade Estadual Paulista Júlio de Mesquita Filho (FAAC-UNESP). Mestre em Ciências da Comunicação e bacharel em jornalismo pela ECA-USP. Email: elizacasadei@ faac.unesp.br.
} 
journalistic photography was constantly re-signified in Brazilian news magazines during the twentieth century. This redefinition has a relation with the different ways in which testimonial function was hinged to news report (in its broadest elements) and how this imperative appeared on its discursive form in writing narrative. As trustee of a narrative intended to be realistic, photojournalism articulates, from techniques and codes of narration, a series of referential and informational strategies. These strategies, however, have changed over time, based on different modes of narration by image and its accreditation in reality.

Keywords: Photojournalism. Testimonial function. History.

\section{Introdução:}

Desde a aparição do termo reportagem, no final do século XIX, a partir de uma modalização específica da crônica jornalística, essa palavra parece ter engendrado certo consenso acerca de suas configurações principais enquanto gênero discursivo. Não obstante esse aparente acordo, contudo, são bastante marcantes as diversas formas narrativas que a reportagem assumiu ao longo do tempo, desde um texto que, em termos gerais, descrevia o trabalho de apuração de um repórter até um modelo jornalístico mais interessado em urdir conjuntos de análises aos dados apresentados. Ao longo do século XX, o termo reportagem, portanto, significou coisas diversas para homens que viveram sob o peso de diferentes épocas históricas e realidades profissionais. Em cada momento, pode ser registrado um conjunto diferente de possibilidades de escrita que refundavam elementos privilegiados do imaginário jornalístico de cada período.

No que concerne à fotografia jornalística, um movimento análogo também pode ser estabelecido. Assim como o texto da reportagem, as imagens que as acompanhavam também seguiram, em cada época histórica, modos narrativos específicos a partir de um determinado arranjo padronizado de seus elementos. Tais arranjos, que também mudavam de tempos em tempos, instauraram diferentes regimes narrativos pela imagem, historicamente marcados, 
nas revistas brasileiras, que articulavam as possibilidades composicionais para que uma imagem fosse considerada sob a rubrica de "jornalística”.

A partir do pressuposto de que as estratégias discursivas utilizadas pelos fotojornalistas obedecem, em seus contornos gerais, a determinados modos padrões de narração pela imagem que instauram códigos de representação socialmente compartilhados, o objetivo do presente artigo é discutir o modo como a função testemunhal da fotografia jornalística foi constantemente ressignificada nas revistas brasileiras de informação ao longo do século XX. Tal ressignificação tem relação com os diferentes modos em que a própria função testemunhal esteve articulada à reportagem (em seus elementos mais amplos) e a forma como esse imperativo aparecia em sua forma discursiva na narrativa.

O caráter de testemunho do fotojornalismo, nesse sentido, também deve ser entendido como uma articulação histórica e não ontológica, de forma que o próprio termo "função testemunhal" é um guarda-chuva que abriga diferentes configurações discursivas na fotografia, apresentando-se enquanto um ato performativo.

Se, no fotojornalismo, é possível dizer que a função testemunhal é uma das articuladoras de sua legitimidade enquanto prática, nem sempre essa função se materializou da mesma forma, como discutiremos a seguir. Como fiduciário de uma narrativa que se pretende realista, o fotojornalismo articula, a partir de técnicas e códigos de narração diversos, uma série de estratégias referenciais e informativas que, contudo, mudaram com o passar do tempo, articulando diferentes modos de narração pela imagem e de credenciamento perante o real.

\section{A função testemunhal como performativo na fotografia jornalística}

A partir de diferentes pressupostos, a função testemunhal da fotografia é constantemente reafirmada, seja porque o noema fotográfico representaria "uma emanação da realidade passada" (BARTHES, 1981, p. 88), seja porque a "fotografia pode distorcer - mas 


\section{míDiA eCOti
DiAno}

\section{PPGMC}

sempre permanece a suposição de que algo semelhante ao que a fotografia mostra existe ou existiu" (SONTAG, 2004, p. 6).

Para Dubois (2001), a fotografia deve o seu efeito testemunhal não ao caráter mimético que ela estabelece com o referente retratado (o parecer-se com o objeto retratado), mas sim, ao ato mecânico de sua inscrição. Em outros termos, o testemunho se liga à imagem fotográfica pelo fato de que a fotografia deve ser descrita por seu caráter indiciário (requisito para a própria formação da imagem fotográfica) e não por sua circunstância icônica - que, a rigor, não é necessária nem determinante para a feitura da fotografia.

De acordo com as próprias palavras de Dubois, posto que "o ponto de partida é a natureza técnica do ato fotográfico, o princípio elementar da impressão luminosa regida pelas leis da química e da física" (ou seja, "em primeiro lugar, o traço, a marca, o depósito"), a fotografia "aparenta-se com a categoria dos signos em que encontramos igualmente a fumaça (indício de fogo), a sombra (indício de uma presença), a cicatriz (marca de um ferimento), a ruína (traço do que havia ali), o sintoma (sinal de uma doença), a marca de passos etc.”. Ela é, portanto, índice da realidade - ainda que eu enquadre, ainda que eu manipule a imagem ou estabeleça um ponto de vista a partir dela, algo (um traço de luz), necessariamente, teve que emergir do objeto para inscrever a imagem. E é nessa inscrição que se sustenta o seu ato testemunhal. Nisso, a fotografia se "diferencia radicalmente dos ícones (que se definem apenas por uma relação de semelhança) e dos símbolos (que, como as palavras da língua, definem seu objeto por uma convenção geral)" (DUBOIS, 2001, p. 50).

Nesses termos, é a necessidade de impregnação mecânica dos raios luminosos para a formação da imagem que garante o seu caráter como testemunha de que um determinado objeto esteve lá (embora ela não testemunhe nada sobre a aparência desse objeto ou sobre o significado que a ele deve ser urdido em um contexto mais amplo). O caráter técnico da fotografia, portanto, esteve na base de teorias que colocaram a noção de dispositivo, o cunho mecânico e as características tecnológicas do ato fotográfico como fundamento e origem da criação de seu efeito testemunhal (enquanto efeito de realidade). 


\section{míDiA eCOti
DiAno}

\section{PPGMC}

Tal como apontado por Picado (2011, p.166), a metafísica do dispositivo fez com que as teorias sobre a fotografia se detivessem na noção de que "o fenômeno fotográfico estivesse como que previamente justificado nesse seu aspecto de rendição instantânea ou de impregnação mecânica do mundo visual numa superfície sensível”, mantendo os aspectos pelos quais a imagem fotográfica entra em outros protocolos culturais de recepção em segundo plano. Para o autor, "a fotografia é assim assumida na condição de um tipo de manifestação da discursividade visual cuja experiência é necessariamente marcada pela relação filogenética entre suas imagens e um dispositivo", em uma determinação que é dada pelo "engenho de visualização" que envolve as suas técnicas (PICADO, 2011, p.167).

Os diversos usos sociais da fotografia, contudo, bem como as reflexões sobre os seus aspectos plásticos e representacionais e sobre os contíguos comunicacionais da imagem fotográfica, fizeram com que as teorias que projetavam o efeito testemunhal à prioridade do dispositivo técnico também precisassem ser reposicionadas. Para Picado (2011, p.170), mesmo em outros campos simbólicos, como na teoria do cinema, por exemplo, lugar no qual o discurso sobre o dispositivo manifestou-se com ênfase, "a noção de que a experiência fílmica pudesse ser um correlato ou efeito da ordem dos aparatos técnicos ou das instituições culturais jamais se propôs como constituindo in se uma arché do cinema, ou então como sobreposta a toda uma outra ordem de variáveis relativas à experiência concreta (social, cultural, estética) de suas imagens".

Se, a partir desses pressupostos, aceitarmos o princípio de que o efeito de testemunho da fotografia não deve estar incrustrado prioritária ou exclusivamente no dispositivo técnico, é necessário, portanto, estabelecer qual é o lugar do efeito de testemunho nas práticas fotográficas.

Embora o efeito de testemunho seja sempre uma presença ostensiva nas reflexões sobre a fotografia, poucas vezes esse efeito foi urdido às mudanças constantes nas práticas sociais que sustentam a própria fotografia e, consequentemente, seus efeitos de realidade e seus usos práticos. É nesse ponto que podemos nos apoiar em autores que entendem o efeito 


\section{míDiA eCOti
DiAno}

\section{PPGMC}

testemunhal não como uma característica ontológica das práticas, mas como um ato performativo, conforme discutiremos a seguir.

A definição de Derrida para o testemunho, nesses termos, é bastante interessante: para ele, o testemunho se configura como "uma promessa de verdade até mesmo no perjúrio" (DERRIDA, 1997, p. 89). Isso significa que o testemunho é um fator de amparo das relações sociais na medida em que não há resposta sem um princípio de responsabilidade: uma vez que "é preciso responder ao outro, diante do outro e de si próprio", a palavra dita não pode ser concebida fora de um campo que envolva uma fé jurada ou um juramento, nos termos sempre de uma ação (ou, em outras palavras, de um "eu comprometo-me a tanto diante do outro a partir do momento em que me dirijo a ele, ainda que só e talvez, sobretudo, se para cometer perjúrio").

Sem a experiência de performativa deste ato de fé elementar, não haveria nem 'laço social', nem endereçamento ao outro, nem qualquer performatividade em geral: nem convenção, nem instituição, nem constituição, nem estado soberano, nem lei, nem, sobretudo, aqui, essa performatividade estrutural da performação produtiva que liga desde o início o saber da comunidade científica ao fazer, a ciência à técnica (DERRIDA, 1997, p. 64).

Afirmar o caráter testemunhal da imagem fotográfica nesses termos significa dizer que ela carrega consigo a ideia de que, por ser um testemunho, a verdade nela é prometida para além de toda a prova e de toda a mostração intuitiva. E assim, "ainda que eu minta ou perjure (e sempre e, sobretudo, quando o faço), prometo a verdade e peço ao outro para crer no outro que sou, aí onde sou eu o único a poder testemunhar e onde nunca a ordem da ordem ou da intuição serão redutíveis ou homogêneas a essa fiduciariedade" (DERRIDA, 1997, p. 64). O testemunho é mesmo, nesses termos, um ato que se afirma enquanto ato performativo.

Também para Agamben, a força do testemunho é dada, prioritariamente, pela força performativa que este assume na linguagem. Uma vez que o performativo pode ser definido como um enunciado que não descreve um estado de coisas, mas sim, que realiza imediatamente o fato na sua enunciação, adquirindo, em sua simples pronúncia, a eficácia de 


\section{ImiDiA eCOti
DiAno}

\section{PPGMC}

um ato, ele só pode se realizar na medida em que efetua a suspensão do caráter denotativo normal da linguagem.

"O verbo performativo constrói-se necessariamente com um dictum que, considerado em si, tem natureza puramente denotativa, e sem o qual ele continuaria vazio ou ineficaz ('eu juro' não tem valor se não for seguido - ou precedido - por um dictum que o preenche)". O que é importante notar, contudo, é o fato de que esse dictum é revogado no mesmo instante em que ele é precedido por esse "eu juro": a sua força denotativa perde importância e proeminência, na medida em que é a força performativa da promessa que adquire o primeiro plano na sentença. E “assim, o performativo substituiu a relação denotativa entre palavra e coisa por uma relação autorreferencial que, excluindo a primeira, põe a si mesma como o fato decisivo" (AGAMBEN, 2011, p. 66).

$\mathrm{Na}$ suspensão da relação denotativa, é o próprio modelo de verdade da representação que é rearticulado a partir do uso do performativo: "o modelo de verdade não é, nesse caso, o da adequação entre as palavras e as coisas, mas sim aquele do performativo, no qual a palavra realiza inevitavelmente o seu significado". E, portanto, "assim como, no estado de exceção, a lei suspende a própria aplicação unicamente para fundar, desse modo, a sua vigência, assim também, no performativo, a linguagem suspende a sua denotação precisamente e apenas para fundar seu nexo existentivo com as coisas" (AGAMBEN, 2011, p. 66).

A implicação disso está no fato de que, no testemunho, é estabelecida uma distinção entre o próprio juramento e o seu conteúdo semântico. Nesses termos, a relação que ele estabelece com o verdadeiro está no seu próprio aspecto formal, independentemente do conteúdo que serve de objeto a esta fé juramentada.

Enquanto articulação formal, portanto, “o juramento não tem a ver com o enunciado como tal, mas com a garantia de sua eficácia: o que nele está em jogo não é a função semiótica e cognitiva da linguagem como tal, mas sim, a garantia de sua veracidade e da sua realização" (AGAMBEN, 2011, p. 12). 


\section{PPGMC}

DiAno

E isso porque, apropriando-se das asserções de Benveniste sobre o testemunho, podese dizer que, embora em sua forma, ele tenha sempre a função de apoiar, garantir e demonstrar algo, ele não é capaz de fundamentar coisa alguma. "Individual ou coletivo, o juramento só existe em virtude daquilo que reforça e torna solene: pacto, empenho, declaração". E assim, "ele prepara ou conclui um ato de palavra que só possui um conteúdo significante, mas por si só mesmo não enuncia nada". Mais do que isso, a sua função de verdade "não reside na afirmação que produz, mas na relação que institui entre a palavra pronunciada e a potência invocada" (BENVENISTE apud AGAMBEN, 2011, p. 12).

Se o juramento é um ato que realiza uma garantia independentemente de o fato enunciado acontecer ou não, é porque a sua força performativa reside na forma, reside em seu significante, independentemente da asserção que o acompanha. Nesses termos, há uma promessa de verdade inserida no testemunho que se instala independentemente do assunto relatado. Ou, de forma mais precisa, que se realiza na forma e não no conteúdo.

Com esses pressupostos, é possível entrever que a força performativa do juramento está na base do testemunho e garante o seu modelo de verdade imaginário.

Em relação ao fotojornalismo, é possível dizer que o testemunho se configura como uma de suas matrizes de verdade presumida na medida em que não importa necessariamente qual é a imagem que o fotógrafo produza: em todas as fotorreportagens existe sempre uma promessa imaginária de verdade que é garantida pelo estatuto social do testemunho - estatuto este que o fotojornalismo se apropria em suas construções de sentido.

Há, ainda, uma outra implicação importante: além disso, é necessário enfatizar o fato de que, uma vez que a sua própria força de verdade está articulada enquanto significante, é nesse aspecto que podemos entrever que ele possui valor enquanto código socialmente compartilhado.

Como nos lembra Aumont (1993, p. 106), “o realismo, enfim, é um conjunto de regras sociais com vistas a gerir a relação entre a representação e o real de modo satisfatório para a 


\section{míDiA eCOti
DiAno}

\section{PPGMC}

sociedade que formula essas regras". Ou, em outros termos, trata-se de um efeito articulado nos e a partir dos códigos socialmente reconhecidos de narração.

É por efeito dos códigos que são engendrados os valores de verdade que dão consistência ao testemunho e é por meio deles que podemos ter acesso aos seus modos de expressão nas fotografias jornalísticas. Nesses termos, a função testemunhal se materializa nas fotografias jornalísticas a partir de estratégias de semantização do acontecimento de ordens diversas e, portanto, é pelo engendramento desses códigos de narração que temos acesso às suas diversas materializações historicamente marcadas. E sob esses termos que podemos posicionar o testemunho nas práticas fotojornalísticas.

Posto que a função testemunhal, enquanto ato performativo, materializou-se de diferentes formas nas produções fotojornalísticas ao longo da história, é possível delimitar os modos de narração pela imagem que acomodaram essa função testemunhal do fotojornalismo ao longo do século XX.

\section{Diferentes articulações testemunhais nas fotografias em revista: intersecções com o texto}

Em trabalhos anteriores, mapeamos o modo como o texto da reportagem mudou ao longo do tempo, instaurando diferentes regimes padrões de narração nas revistas do século XX no Brasil (CASADEI, 2013). Curiosamente, os regimes padrões de narração textual foram acompanhados pela mudança nos regimes padrões de narração pela imagem, o mostra como a articulação da função testemunhal em um espectro mais amplo, abarcando a reportagem em seu conjunto.

A Revista da Semana, fundada em 1900, é considerada a primeira revista brasileira em que a fotografia passa, efetivamente, a ter um lugar de destaque no projeto editorial da publicação e, por isso, pode-se dizer que ela consolidou certo tipo de imaginário visual no 
jornalismo em revista ${ }^{2}$. Baseada no enaltecimento da fotografia enquanto meio para contar estórias, essa nova proposta em termos de revista ilustrada é posta logo no editorial de apresentação da Revista da Semana, que descrevia a missão da publicação nos seguintes termos:

de tudo quanto se passar durante a semana e que mereça atenção, procurará dar, em excelentes gravuras, copiadas de fotografias, o que deva exercitar a curiosidade pública. Quando o caso assim exigir, juntar-se-a a isso o texto necessário para a boa compreensão dos fatos, embora, em regra, nos empenhemos em multiplicar de tal modo as estampas, escolhendo-as tão bem que dispensem comentários. Onde houver o que agrade ou impressione os espíritos curiosos, haverá um operador da Revista fotografando-o (REVISTA DA SEMANA, 30/12/1922).

A ênfase na fotorreportagem em detrimento da matéria escrita, portanto, já estava anunciada desde o início enquanto proposta editorial. Esse é um aspecto, inclusive, presente em muitas publicações da mesma época. A valorização da linguagem visual era tão expressiva que é possível encontrar, em vários editoriais de lançamento de revistas, a argumentação de que "os textos explicativos só apareceriam quando necessário, já que os recursos visuais seriam enfáticos e atraentes" (VELLOSO, 2006, p. 327), insistindo na ideia de centralidade do visual.

Por sua ênfase no uso de imagens, Buitoni (2007) considera que, durante muito tempo, a Revista da Semana foi mesmo "a responsável pelo imaginário visual brasileiro". E assim, em suas páginas, comumente podemos encontrar "comemorações, paisagens, personagens, que iam mostrando caras e cenas posadas; um ou outro flagrante, numa estética bastante ufanista".

\footnotetext{
${ }^{2}$ Para conseguir a tecnologia necessária para o seu projeto de compor uma revista em que a fotografia fosse o destaque da publicação, Álvaro Teffé, fundador da Revista da Semana, teria ido à Paris buscar os equipamentos fotográficos que o seu projeto requeria. Conta-nos Costa $(2007$, p. 280) que, "à última hora, os dois técnicos contratados, temerosos dos perigos das epidemias de febre amarela que assolavam o Rio, recusaram-se a embarcar. Não lhe restou alternativa senão fazer, ele mesmo, um rápido aprendizado numa oficina parisiense para ensinar os segredos da nova técnica aos zincógrafos que trabalhavam nas oficinas do Jornal do Brasil".
} 


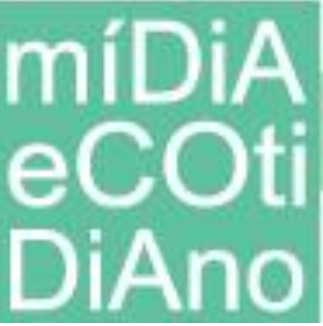

No começo do século XX, tratava-se de fotos que, de uma maneira geral, eram ainda um tanto estáticas - o que, segundo Buitoni (2007, p. 19) mostra que a fotografia ainda conservava a linguagem de suas origens, calcada no desenho e na pintura - de forma que as

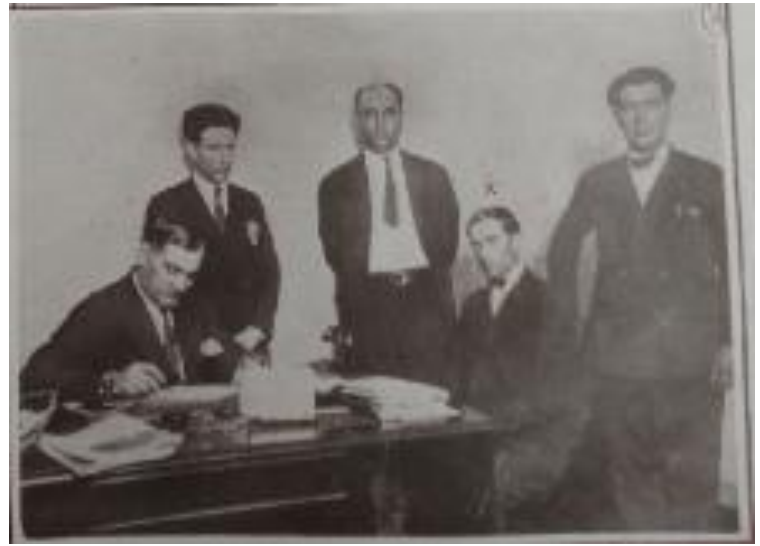

inaugurações, as competições esportivas ou as

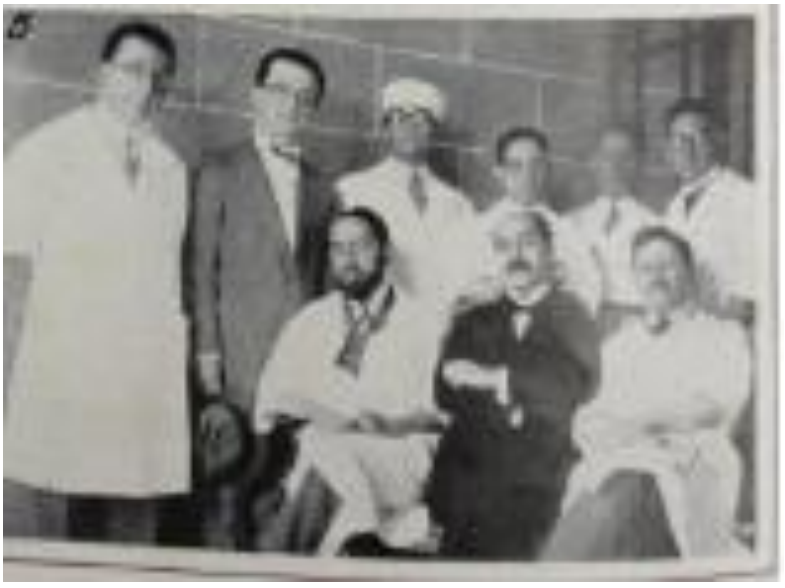

visitas de personalidades ilustres e políticos ao Brasil eram documentadas a partir de fotos posadas e protocolares. O movimento na fotografia será uma técnica adotada mais tarde, em torno da década de 1940, como pode ser observado nas fotografias da Revista da Semana colocadas abaixo:

A fotografia estática é mesmo a marca da imprensa brasileira até, pelo menos, o final da década de 1930, com composições sem grande profundidade de campo, com equilíbrio estático e marcadas pelo olhar direto do retratado para a câmera. Havia, certamente, o fato de que os próprios recursos técnicos disponíveis acabavam por direcionar o trabalho do fotógrafo, fazendo com que ele preferisse realizar fotografias posadas em suas composições (especialmente de personalidades e ícones políticos) e de paisagens estáticas. Os aparelhos fotográficos eram ainda grandes e pesados o que, em grande medida, dificultava o movimento. 


\section{míDiA eCOti
DiAno}

\section{PPGMC}

Essa articulação composicional da fotografia, contudo, embora determinada por expedientes técnicos, acabava por engendrar um efeito de testemunho interessante a partir da articulação entre a fotografia e o texto.

Conforme destacamos em outras ocasiões (CASADEI, 2013), a articulação da função testemunhal na parte escrita das reportagens da Revista da Semana estava toda engendrada a partir do explicitamento do repórter enquanto actante narrativo, em um texto em que o próprio trabalho da reportagem é descrito em detalhes, com uma proeminência bastante acentuada no papel do jornalista, nas suas impressões e nos seus métodos de apuração marca de uma imprensa que adora remeter a si própria, para além do fato noticiado.

Um texto típico da Revista da Semana era, por exemplo, o exposto a seguir, em que essas marcas do repórter ficam bem visíveis a todo o momento na reportagem.

\footnotetext{
Há muitos anos já que os acontecimentos restritos unicamente aos noticiários policiais não nos faziam abalar da redação para o local de um crime ou de uma catástrofe de repercussão nacional. Agora, porém, sob as vistas curiosas de uma multidão de proletários e indigentes, entre os elementos de uma caravana policial, cercados pelos colegas dos jornais diários, eis-nos novamente às voltas com um sensacional caso de morte (REVISTA DA SEMANA, 03/11/1945).
}

Para além desta referência inicial ao trabalho da imprensa, todo o relato prossegue a partir da adoção do ponto de vista do lugar ocupado pelo repórter e suas impressões. Diferentemente do que estamos acostumados nas reportagens atuais, a essas impressões do repórter não se contrapõem entrevistas com os presentes no local, nem mesmo com o delegado que conduzia as investigações ou com os acusados - toda a articulação do relato é dada pela fala do repórter que, no nível textual, se coloca como a principal testemunha e narrador em primeira pessoa. O seu papel enquanto testemunha é reforçado, ainda, por uma ênfase na descrição do trabalho dos outros profissionais da imprensa que estavam no local.

Em termos mais precisos, é possível dizer que, nas reportagens da Revista da Semana, é o repórter o actante narrativo que monopoliza a função testemunhal do narrado: é em torno de seu testemunho que se articula o modelo de verdade do relato tecido. Nas narrativas da 


\section{míDiA eCOti
DiAno}

\section{PPGMC}

Revista da Semana, o repórter funciona como um actante que não apenas organiza o espaço textual, mas sim, que monopoliza a função testemunhal enquanto prova de verdade imaginária. Se, ao longo do século $\mathrm{XX}$, a narrativa jornalística em revista irá eleger outros actantes para cumprir essa função, neste momento, esta é função do personagem-repórter.

Tal como apontado por Duccini (2013, p.26), essa articulação da função testemunhal trabalha com "uma qualidade estética (...) em que a legitimidade do relato não mais se atesta pela objetividade, mas pela ênfase no lugar de onde se enuncia: o espaço de uma experiência irredutível, particular, em oposição às categorias universalizantes". E é nesse sentido que "as narrativas que se ordenam por um efeito de real deslizam então de um realismo de matiz histórico para um realismo dos afetos, das subjetividades".

Nesse jogo, é a realidade da inscrição que toma o primeiro plano da narrativa, em que se enfatiza o envolvimento e o engajamento do narrador com aquilo que é objeto de sua narração. "O realismo dos afetos", portanto, "tem na ênfase da experiência subjetiva seu valor ético e estético". É assim que "as dimensões do testemunho, da autorrepresentação, do envolvimento pessoal com aquilo que narra, do sofrimento (no sentido patético) que se experimenta 'em primeira pessoa' e, eventualmente, do amadorismo ganham compleição" (DUCCINI, 2013, p.83).

Essa urdidura narrativa específica, típica das reportagens da Revista da Semana, manifesta não apenas uma característica do texto, mas sim, um espectro mais amplo do modo como a função testemunhal funcionava naquele modelo de jornalismo, de forma que ela se coaduna com a forma como a função testemunhal estava posta nas próprias fotografias.

As fotografias publicadas na Revista da Semana partilhavam algumas características composicionais comuns, que podem ser observadas nas Imagens 1 e 2, acima. Em primeiro lugar, fica óbvia a formação de uma pose estática.

A pose fotográfica, para Machado (1989, p. 44), é "uma tentativa de fixar a eternidade nesse instante fugaz em que o obturador dá a sua piscadela; é a luta para introjetar no momento aleatório da fotografia o momento ideal da pintura". E é por isso que, "para 


\section{PPGMC}

DiAno

reprimir o inconsciente que pulsa no obturador da câmera, nós nos petrificamos diante dele, como uma estátua grega ou renascentista, e forjamos no bronze de nosso corpo a imagem ideal que supomos ser ou que queremos ser". Tal como uma "armadura arcaizante", a pose é mesmo "uma espécie de vingança do referente: se for inevitável que a câmera roube alguma coisa de nós, que ela roube então uma ficção" (MACHADO, 1989, p. 45).

Além de serem claramente posadas, é possível perceber que essa pose não era aleatória ou composta de qualquer forma: as suas características faziam com que o aparato fotográfico ficasse explícito a todo o momento na representação. A fotografia da Revista da Semana é composta a partir de um personagem que olha diretamente para a câmera e, ao fazê-lo, explicita não apenas o aparato, como também a presença ostensiva do repórter no local do fato, posicionando-o como um personagem pressuposto na fotografia.

A esfera testemunhal, nas reportagens da Revista da Semana, está articulada justamente a partir desse efeito de real que se constrói a partir do investimento pessoal do repórter. No texto, isso se materializa a partir do repórter enquanto actante que monopoliza a função testemunhal; na imagem, isso se dá a partir do olhar do fotografado para o aparato que, a partir de um efeito de quebra da quarta parede, explicita a presença do repórter no local do fato noticiado.

Para essa articulação narrativa específica da função testemunhal na fotorreportagem, é a corporalidade do repórter que garante o cumprimento da veracidade do relato. O repórter era o actante narrativo central que fornecia o lastro de veracidade do relato; era ele quem assumia o papel do fiador que supostamente garantiria não apenas que o acontecimento aconteceu, mas que ele se processou daquela maneira específica já que ele o viu. A fotografia, articulada dessa forma, com o olhar ostensivo do retratado para o repórter e para o aparato, garantia que o jornalista, de fato, estava lá.

Para além das fotografias posadas, é possível encontrar, nas páginas da Revista da Semana, uma outra série de fotografias que enfatizam o próprio trabalho do repórter, mostrando a sua presença in loco, conforme exemplificado pelas fotografias a seguir: 


\section{míDiA eCOti}
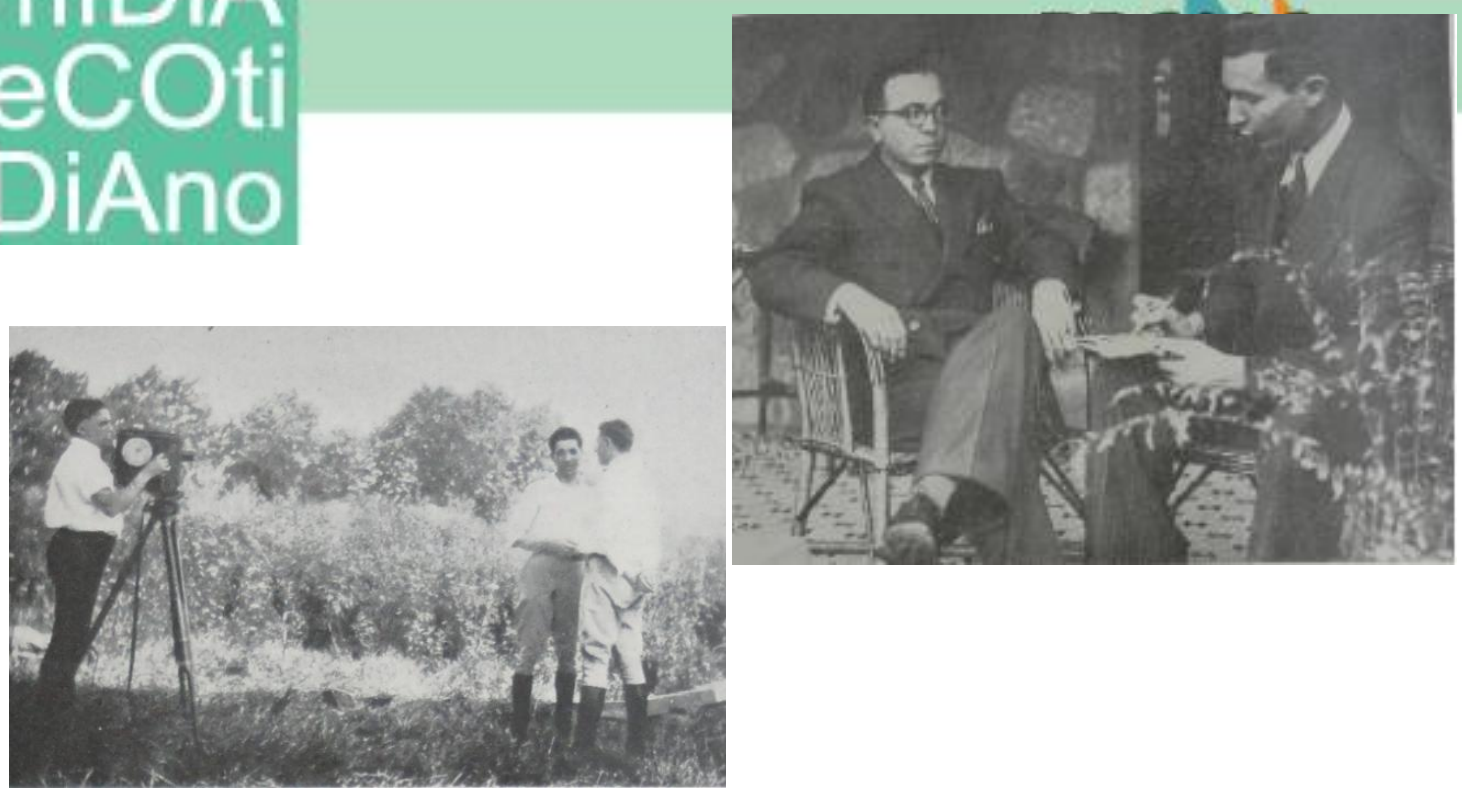

Imagem 3: Revista da Semana, 24/02/1923

Imagem 4: Revista da Semana, 12/07/1941

Nessas imagens, o repórter/fotógrafo aparece não somente como personagem pressuposto na imagem, mas como um actante visível na composição fotográfica.

Essa configuração narrativa da função testemunhal no fotojornalismo será rearticulada a partir dos anos 1940. Essa mudança será fruto de inovações tecnológicas (como a adoção das câmeras de formato 135, que permitiam uma melhor mobilidade do fotógrafo, e os filmes que dispensavam o uso de flash), mas acaba por engendrar uma nova formulação da função testemunhal na fotografia e em sua relação com o texto mais amplo da reportagem.

A fotografia jornalística brasileira passa a adotar padrões europeus e norte-americanos a partir dos anos 50, com o abandono das antigas fotos posadas. Nesse quesito, O Cruzeiro encabeça os novos padrões no imaginário da visualidade nacional na década de 1940.

As mudanças na imagem são acompanhadas por outras formas de urdiduras textuais, de forma que outros códigos padrões de narração assumem o primeiro plano do relato, com consequências para a materialização da função testemunhal na reportagem. Em O Cruzeiro, embora o testemunho do repórter continue a exercer um papel essencial enquanto matriz de verdade presumida no jornalismo de revista, outras figuras testemunhantes passam a dividir o espaço com o repórter (não enquanto sujeito empírico, mas sim, em sua posicionalidade 
como personagem atuante na narrativa), rearticulando, com isso, a própria função testemunhal no jornalismo. Ao contrário do período anterior, o repópter 1 SSa/4/ experiência com outros atores participantes do evento. Ele passa a dividir a uffinção testemunhal com outras testemunhas (CASADEI, 2013).

Mesmo que o texto ainda seja escrito em primeira pessoa, a partir da década de 1940, O Cruzeiro passa a adotar novas formas estéticas de materialização da voz da fonte no nível da narrativa da reportagem - um procedimento que, mesmo nesta época, era pouco usado pela Revista da Semana. A voz da fonte, finalmente, se autonomiza da voz do repórter, sem que a voz do jornalista tenha que falar por elas, servindo-lhes como fiador. Nas reportagens de $O$ Cruzeiro, portanto, não é mais o repórter que tem os privilégios exclusivos da função testemunhal: a partir deste momento, outras vozes são ouvidas na narrativa e outros atores passam a exercer o testemunho enquanto ato, ou seja, a confiabilidade do relato não depende mais da exclusividade da corporalidade do repórter enquanto instância fiadora do relato.

É interessante notar como essa rearticulação da função testemunhal na reportagem como um todo também se coaduna aos novos regimes de imagem praticados por O Cruzeiro. As fotografias posadas, com o retratado que olha diretamente para a câmera são substituídas por imagens que valorizam o acontecimento e escondem o aparato. 

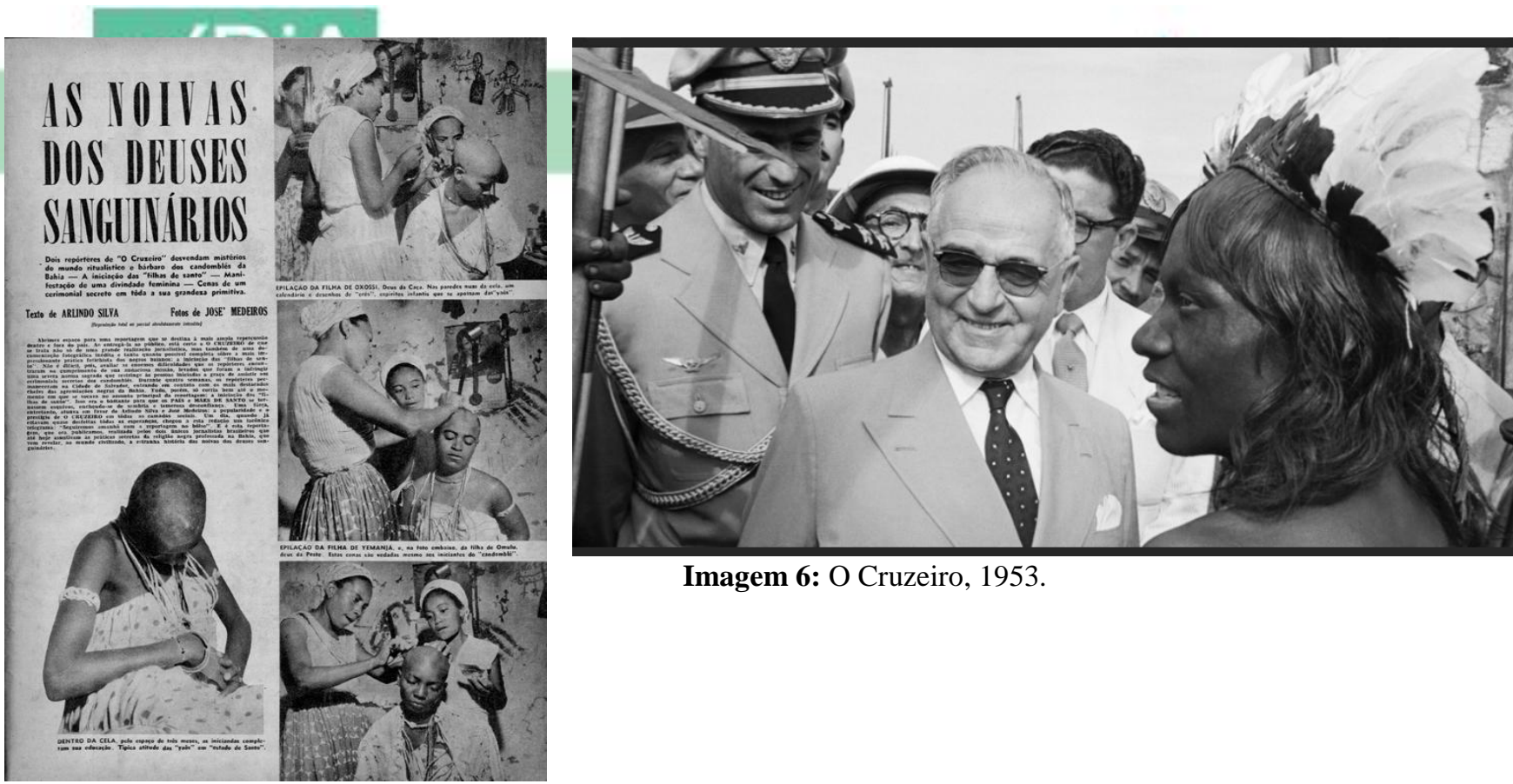

Imagem 6: O Cruzeiro, 1953.

Imagem 5: O Cruzeiro, 1951

As fotografias de $O$ Cruzeiro, para Jaguaribe e Lissovsky (2006, p. 90), "pretendiam ser bem mais do que meras ilustrações. Conformam um gigantesco empreendimento pedagógico e publicitário autônomo, que faz uso de várias estéticas modernas para representar 'a invenção do futuro no presente'", no intuito de tornar visível a modernização brasileira. Ainda no que concerne à fotografia, a incorporação de outras linguagens midiáticas à estrutura da revista se fazia sentir por toda a sua elaboração. Como aponta Dines (1986, p. 73), "a reação em cadeia provocada pela TV", por exemplo, atingiu as revistas ilustradas quando "começou-se a usar a cor regularmente em O Cruzeiro e Manchete, em 1957, como ação preventiva contra a invasão em preto e branco da TV'.

Para Leite (2011), é possível identificar duas linhas distintas de composição e linguagem fotográfica na revista: em um primeiro grupo, encontravam-se fotógrafos que se preocupavam com a construção da cena fotografada (como Jean Manzon, Indalécio Wanderley, Peter Sheir e Ed Keffel), em imagens elaboradas e com a utilização de máquinas de grande formato. No outro grupo, pode-se posicionar fotógrafos que preferiam a utilização de máquinas mais compactas e leves, de pequeno formato, mais ligados a um jornalismo de acontecimentos, mais contemporâneo, com representantes como José Medeiros, Flávio Damm e Eugênio Silva. 


\section{míDiA \\ eco DiAno}

\section{PPGMC}

Nas duas linhas, contudo, é bastante claro o modo como o personagem é valorizado na ação, de forma que o surgimento da autonomização da fonte na narrativa escrita é acompanhado pelo engrandecimento da fonte na composição imagética.

Se preferirmos os termos de Gombrich (2012), a mudança na composição imagética entre a Revista da Semana e O Cruzeiro representa uma passagem no modo como era representada a ação narrativa: se, na primeira, havia uma valorização de $o$ quê na fotografia, O Cruzeiro passa a retratar o como da ação na imagem, em uma solução visual que propõe uma dramatização do ato retratado no texto.

Ao valorizar o como da ação, a fotografia se descola da proeminência dada ao repórter no primeiro período: enquanto mais um dos actantes narrativos presentes na narração do acontecimento, a ênfase da ação fotográfica se desloca para os outros personagens envolvidos na ação e para a forma de seu envolvimento dramático.

Em termos de mudanças narrativas nas reportagens em revistas, é possível perceber que, a partir da década de 1960, um outro modelo de reportagem é articulado, vinculado ao jornalismo interpretativo. A partir desse período, há o apagamento do repórter que narra em primeira pessoa e a adoção de outros códigos padrões de narração. Em sua definição clássica para o termo "jornalismo interpretativo", Beltrão (1976) já afirmava que esse estilo de reportagem tem como finalidade ampliar a informação dada por outras instâncias midiáticas, de forma que a narrativa se mobiliza para estabelecer o significado de um fato já conhecido.

Enquanto as revistas do período anterior alicerçavam na função testemunhal a principal prova imaginária de verdade em suas reportagens, com uma ênfase bastante explícita na corporalidade da testemunha enquanto pacto que garante a fiabilidade do narrado, nas revistas mais recentes, esse mecanismo está presente apenas de uma maneira secundária. Veja foi uma das primeiras publicações a adotar plenamente esse modelo de reportagem no Brasil.

Embora em algumas (poucas) reportagens, o repórter assuma o primeiro plano do relato, de uma maneira geral, há mesmo o apagamento de sua figura enquanto actante 


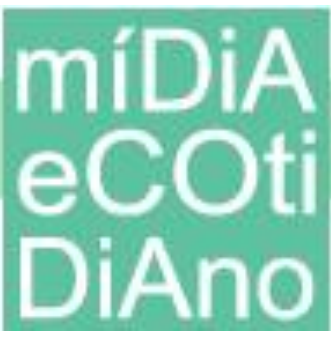

narrativo e a colocação, em primeiro plano, de códigos padrões de narração ligados a provas

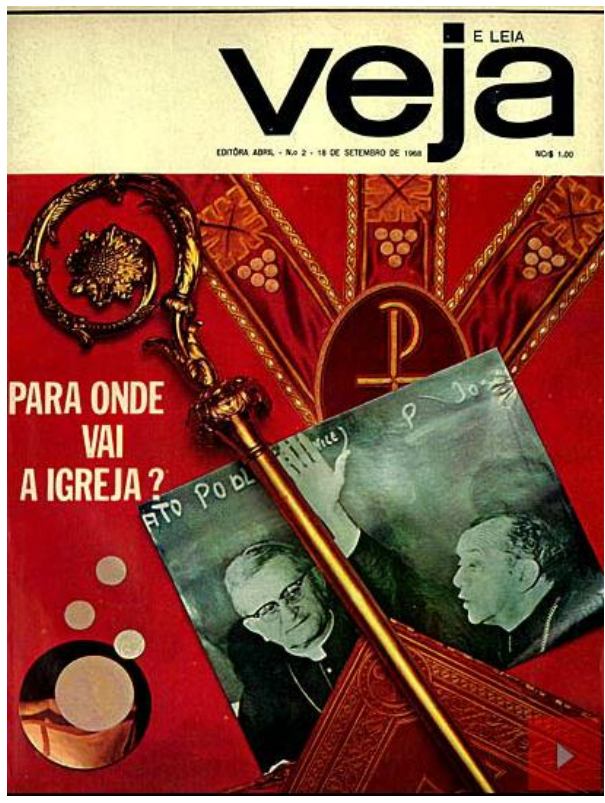

Imagem 7: Veja, 18/09/1968 de verdade externas ao próprio acontecimento narrado (quantificações, demarcações da ciência, analogias). Enquanto a esfera do testemunho como lastro imaginário que garantia a veracidade do relato se contrai (apenas as testemunhas em terceira pessoa que continuam a assumir essa função), há uma explosão de um novo conjunto de provas de verdade articuladas na narrativa (CASADEI, 2013).

Não é ocasional o fato de que é justamente nesse período que a fotoilustração ganha proeminência nas revistas informativas. Esse tipo de produção fotográfica está em consonância com a rearticulação da função testemunhal nesse modelo de jornalismo.

A fotoilustração é um tipo de produção fotográfica que subverte a ideologia de captura do acontecimento do fotojornalismo, posto que o seu objetivo é ilustrar um tema de forma que a imagem expresse um determinado conceito ou ideia abstrata. A fotoilustração é, portanto, sempre um gênero opinativo, posto que a sua feitura se estrutura a partir do explicitamento do ponto de vista defendido na reportagem. A fotoilustração oferece ao leitor a condensação de sua opinião através de uma imagem forte. É nesse sentido que o mundo factual, na fotoilustração, não importa tanto quanto a interpretação que é dada a esse mundo factual.

A partir do pressuposto de que as estratégias testemunhais dos textos jornalísticos estão em coadunação com as estratégias testemunhais das fotografias jornalísticas que os acompanham, o surgimento da fotoilustração tem coerência e sentido apenas nesse modelo de reportagem, em que há a refração da função testemunhal na notícia como um todo e um deslocamento para a interpretação do fato. 


\section{míDiA eCOti DiAno}

\section{Considerações Finais}

Para Susan Sontag (2004, p. 32), as fotografias "são apreciadas porque dão informações. Dizem o que existe; fazem um inventário". Não obstante isso, "nas situações em que a maioria das pessoas usa as fotos, seu valor como informação é da mesma ordem que o da ficção". A carga de ficcionalidade no fotojornalismo é urdida, justamente, por seu caráter narrativo, de forma que, tal como posto por Manguel (2001, p. 27), "quando lemos imagens (...), atribuímos a elas o caráter temporal da narrativa. Ampliamos o que é limitado por uma moldura para um antes e um depois por meio da arte de narrar”.

As diferentes articulações da narrativa na fotografia jornalística em revista asseveram as diversas configurações da função testemunhal no fotojornalismo. Isso se manifesta na forma como a ação e o os personagens foram mostrados ao leitor ao longo do tempo, nas interações diversas entre a linguagem fotográfica e a parte escrita da reportagem, bem como nos diferentes pactos de leitura estabelecidos entre o fotógrafo e o leitor para a criação de um efeito de testemunho. Nesse sentido, o testemunho, na fotografia jornalística, não é um mero efeito do dispositivo, mas está mediado pelo caráter performativo de sua linguagem que faz uma promessa de verdade ainda que em perjúrio a partir de diferentes configurações discursivas. 


\section{míDiA eCOti
DiAno}

\section{PPGMC}

\section{Referências}

AGAMBEN, G. O Sacramento da Linguagem. Belo Horizonte: Editora UFMG, 2011.

AUMONT, J. A Imagem. Campinas: Papirus, 1995.

BARTHES, R. A Câmara Clara. Rio de Janeiro: Nova Fronteira, 1984.

BELTRÃO, L. Jornalismo interpretativo. Porto Alegre: Sulina, 1976.

BUITONI, D. H. S. "Fotografia e Jornalismo: da prata ao pixel”. Líbero, ano X, n. 20, 2007, p. 103-112.

CASADEI, E. B. Os Códigos Padrões de Narração e a Reportagem: por uma história do jornalismo de revista no século XX. Tese de Doutorado apresentada à Escola de Comunicações e Artes da Universidade de São Paulo. São Paulo: ECA-USP, 2013.

COSTA, C. R. A Revista no Brasil, o século XIX. Tese de Doutorado apresentada à Escola de Comunicações e Artes da Universidade de São Paulo. São Paulo: ECA-USP, 2007.

DERRIDA, J. "Fé e Saber: as duas fontes da 'religião' nos limites da simples razão". In DERRIDA, J. e VATTIMO, G. (dir.). A Religião: seminário de Capri. Lisboa: Relógio D’Água, 1997.

DUBOIS, P. O ato fotográfico e outros ensaios. Campinas: Papirus, 2001.

DUCCINI, M. Ponto de Vista A(u)torizado: composições da autoria no documentário brasileiro contemporâneo. Tese de Doutorado (Ciências da Comunicação). São Paulo: ECA-USP, 2013.

GOMBRICH, E. H. Os usos das imagens. Porto Alegre: Bookman, 2012.

JAGUARIBE, B.; LISSOVSKY, M. "Imagem fotográfica e imaginário social”. ECO-PÓS, v.9, n.2, agosto-dezembro de 2006.

LEITE, M. E. "O fotojornalismo na $O$ Cruzeiro: uma aproximação". Anais do $9^{0}$ Encontro Nacional de Pesquisadores em Jornalismo. Rio de Janeiro, novembro de 2011.

MACHADO, A. A ilusão especular. São Paulo: Brasiliense, 1989.

MANGEL, A. Lendo Imagens. São Paulo: Companhia das Letras, 2001.

PICADO, B. "Sobre/Pelo/Contra o Dispositivo: revisitando a arché da fotografia". Matrizes, v. 4, n. 2, janeiro-junho de 2011, p.165-181.

SONTAG, S. Sobre Fotografia. São Paulo: Companhia das Letras, 2004.

VELLOSO, M P. "Percepções do moderno: as revistas do Rio de Janeiro". In NEVES, Lucia Maria Bastos, MOREL, Mario e FERREIRA, Tania Maria Bresson (org.). História e Imprensa. Rio de Janeiro: DP\&A, 2006. 